Volume 3 Issue 1, March 2018: pp. 119-128. Copyright @ LamLaj. Faculty of Law, Lambung Mangkurat University, Banjarmasin, South Kalimantan, Indonesia. ISSN: 2502-3136 | e-ISSN: 2502-3128. Open Access at: http://lamlaj.ulm.ac.id/web/

\title{
URGENSI JAMINAN FIDUSIA DALAM PERJANJIAN LEASING
}

\author{
Zakiyah $^{1}$, Tavinayati ${ }^{2}$ \\ ${ }^{1}$ Fakultas Hukum Universitas Lambung Mangkurat. Jl.Brigjend H.Hasan Basri \\ Banjarmasin 70123 Indonesia Fax:05114321658+E-mail : zakiyahmst@gmail.com \\ ${ }^{2}$ Fakultas Hukum Universitas Lambung Mangkurat. Jl.Brigjend H.Hasan Basri \\ Banjarmasin 70123 Indonesia Fax: $05114321658+$ +E-mail : tavi_ampah@yahoo.com
}

Submitted : 16/03/2018 Reviewed 19/03/2018 Accepted:22/03/2018

\begin{abstract}
Abtract: Every business activity needs capital either in the form of funds or capital goods. Capita good procurement needs large capital funds. The steps usually taken by the company to fulfil the needs of capital goods is by renting to finance companies such as leasing. In the lease agreement, the ownership of capital goods is on the Lessor (finance company), then what is the need of Lessor binding the Lessee with fiduciary guarantee. The aim of this study is to know the characteristics of the lease agreement and the the purpose of binding the object of the lease with fiduciary guarantee. The method used is the type of normative legal research which is the research research that refers to the norms contained in the legislation and lease contract documents widely used in leasing companies. The result of the research shows that lease agreement has special characteristics because it consists of three types of agreement, which are sale and purchase agreement, rental agreement and lease agreement. During the lease agreement takes place, The ownership of the lease object is in lessor (finance company / creditor), so that when bound by fiduciary guarantees meaning as an excessive measure, but in the practice, from the beginning of the lease agreement, the ownership of the leasing object has been on behalf of the lessee (debtor) for the reasons of efficiency. therefore, to avoid losses due to the default debtor, the lessor completes the lease agreement followed by fiduciary guarantee.
\end{abstract}

Keywords:Fiduciary Guarantees; Leasing Agreements; Urgency

Abstrak: Setiap kegiatan usaha memerlukan modal baik dalam bentuk dana mau-
pun barang modal. Pengadaan barang modal memerlukan dana yang besar. Lang-
kah yang biasa diambil oleh perusahaan untuk memenuhi kebutuhan barang modal
adalah dengan menyewa kepada perusahaan pembiayaan seperti leasing. Dalam
perjanjian leasing, kepemilikan atas barang modal berada pada Lessor (perusa-
haan pembiayaan), lantas apa perlunya Lessor mengikat Lessee dengan jaminan 
fidusia. Tujuan penelitian ini adalah untuk mengetahui karakteristik dari perjanjian leasing dan untuk apa objek leasing diikat dengan jaminan fidusia. Metoda yang digunakan adalah jenis penelitian hukum normatif yaitu penelitian yang mengacu pada norma-norma yang terdapat dalam peraturan perundang-undangan dan dokumen kontrak leasing yang banyak digunakan di perusahaan leasing. Hasil penelitian menunjukkan bahwa perjanjian leasing memiliki karakteristik khusus karena didalamnya mengandung tiga jenis perjanjian, yaitu: perjanjian jual beli, perjanjian sewa menyewa dan perjanjian sewa beli. Selama perjanjian leasing berlangsung kepemilikan objek leasing berada pada lessor (perusahaan pembiayaan/kreditur), sehingga apabila diikat dengan jaminan fidusia hal ini merupakan perbuatan yang berlebihan, namun dalam pakteknya seringkali dengan alasan efesiensi dimana sejak awal perjanjian leasing kepemilikan objek leasing sudah diatasnamakan lessee (debitur), sehingga untuk menghindari kerugian akibat debitur wanprestasi, maka lessor melengkapi perjanjian leasing tersebut diikuti dengan jaminan fidusia.

\section{Kata Kunci: Jaminan Fidusia; Perjanjian Leasing; Urgensi}

\section{PENDAHULUAN}

Setiap kegiatan usaha memerlukan modal, baik dalam bentuk dana maupun barang modal. Dana diperlukan untuk operasional perusahaan, sedangkan barang modal diperlukan untuk mendukung kegiatan perusahaan. Sebuah perusahaan tambang misalnya tentu memerlukan alat berat untuk kegiatan eksploitasi tambang dan alat angkut untuk mengangkut hasil tambang.

Pengadaan untuk barang modal memerlukan dana yang besar, sementara dana yang dimiliki perusahaan lebih diprioritaskan untuk mendanai operasional perusahaan yang lain. Langkah yang diambil oleh perusahaan untuk memenuhi kebutuhan barang modal adalah dengan menyewa barang modal pada perusahaan pembiayaan. Penyewaan barang modal oleh perusahaan yang memerlukan barang modal pada perusahaan pembiayaan dikenal dengan perjanjian leasing

Perjanjian leasing sebenarnya mirip dengan perjanjian sewa menyewa biasa sebagaimana yang diatur dalam Pasal 1548 sam- pai dengan Pasal 1600 Kitab Undang-undang Hukum Perdata (Staatsblad 1847 Nomor 23, untuk selanjutnya disebut KUH Perdata) hanya objek sewanya yang berbeda. Leasing hanya mengkhususkan pada barang modal, yakni barang yang diperlukan untuk kegiatan usaha. Dalam perjanjian sewa menyewa, objeknya adalah barang pada umumnya, baik itu barang untuk produksi maupun barang untuk konsumsi.

Meskipun ada perbedaan pada objek sewanya, tetapi ada persamaan antara leasing dengan sewa menyewa biasa yakni pada kedudukan penyewa dan lessee, yakni samasama sebagai pengguna dari barang yang disewakan, bukan pemilik dari barang yang disewanya. Dalam perjanjian leasing pihak yang menyewakan barang modal disebut dengan lessor, sedangkan pihak penyewa barang modal disebut lessee.

Apabila lessor adalah pemilik dari barang modal, mengapa seringkali dalam praktik lessor mengikat lessee dengan jaminan fidusia. Secara normatif jaminan fidusia itu diperlu- 
kan apabila barang yang dijadikan jaminan utang itu berada didalam penguasaan debitur. Untuk mengantisipasi debitur agar tidak memindahtangankan barang jaminan kepada pihak ketiga, maka kreditur mengingkat debitur dengan jaminan fidusia.

Jaminan fidusia adalah hak jaminan atas benda bergerak baik yang berwujud maupun yang tidak berwujud dan benda tidak bergerak khususnya bangunan yang tidak dapat dibebani hak tanggungan sebagaimana yang dimaksud dalam Undang-Undang Nomor 4 Tahun 1996 tentang Hak Tanggungan Atas Tanah Beserta Benda-benda yang Berkaitan dengan Tanah (Lembaran Negara Republik Indonesia Tahun 1996 Nomor 42, Tambahan Lembaran Negara Republik Indonesia Nomor 3632) yang tetap berada dalam penguasaan Pemberi Fidusia, sebagai agunan bagi pelunasan utang tertentu, yang memberikan kedudukan yang diutamakan kepada Penerima Fidusia terhadap kreditor lainnya. Batasan jaminan fidusia tersebut ditegaskan dalam Pasal 1 angka 2 Undang-Undang Nomor 42 Tahun 1999 tentang Jaminan Fidusia (Lembara Negara Republik Indonesia Tahun 1999 Nomor 168, Tambahan Lembaran Negara Republik Indonesia Nomor 3889; untuk selanjutnya disebut UU No. 42/1999). Pengikatan jaminan fidusia ini biasanya dilakukan pada perjanjian pembiayaan konsumen dan perjanjian jual beli dengan angsuran. Pada kedua jenis perjanjian tersebut hak milik sudah beralih bersamaan dengan penyerahan barang dari penjual (kreditur) kepada pembeli (debitur). Sisa dari harga yang belum dibayar dianggap sebagai utang. Dengan demikian, sangatlah wajar apabila untuk perjanjian pembiayaan konsumen dan perjanjian jual beli dengan angsuran diikat dengan jaminan fidusia, karena barang sudah menjadi milik debitur.
Hal ini berbeda dengan perjanjian leasing, di mana secara yuridis kepemilikan barang tetap pada lessor, apa perlunya lessor mengikat lessee dengan jaminan fidusia. Apakah tindakan lessor ini dapat dikatakan berlebihan? Dengan kata lain, pengikatan jaminan fidusia itu sia-sia saja karena tidak ada manfaatnya? Kalau pengikatan jaminan fidusia dalam perjanjian leasing tidak ada manfaatnya, mengapa lessor melakukan pengikatan jaminan fidusia segera setelah ia mengadakan perjanjian leasing dengan lessee? Untuk itu, maka perlu dikaji lagi isu-isu hukumnya, mengenai karakteristik dari perjanjian leasing dan objek leasing yang diikat dengan jaminan fidusia.

\section{METODE}

Jenis penelitian yang digunakan ini adalah penelitian hukum normatif, yaitu penelitian yang mengacu pada norma-norma yang terdapat dalam peraturan perundang-undangan. Penelitian dilakukan dengan studi dokumen terhadap bahan hukum primer maupun bahan hukum sekunder, yang terkait dengan masalah yang diteliti. Juga diteliti contoh-contoh kontrak leasing yang selama ini dipraktikan oleh perusahaan-perusahaan pembiayaan. Adapun tipe dalam penelitian ini adalah kekaburan norma. Kekaburan norma ini terjadi, karena ketidakjelasan mengenai pranata hukum leasing itu sendiri dalam sistem hukum perjanjian di Indonesia. Penelitian ini bersifat perspektif analitis.

Kemudian semua bahan hukum yang sudah terkumpul diinventarisir dan diidentifikasikan sesuai dengan permasalahan yang telah dirumuskan. Selanjutnya dianalisis secara kualitatif dengan menggunakan tahapan berpikir sistematis guna menemukan jawaban atas permasalahan dalam penelitian ini. 
ANALISIS DAN PEMBAHASAN

\section{Karakteristik Perjanjian Leasing Sebagai} Perjanjian Tidak Bernama

Salah satu asas yang sangat penting dalam hukum perjanjian adalah asas kebebasan berkontrak. Asas kebebasan berkontrak merupakan konsekuensi dari sistem terbuka yang dianut oleh Buku III KUH Perdata. Asas ini disimpulkan dari Pasal 1338 ayat (1) KUH Perdata berbunyi: "Semua persetujuan yang dibuat secara sah berlaku sebagai undang-undang bagi yang membuatnya". Kata "semua" dalam rumusan Pasal 1338 ayat (1) KUH Perdata tersebut menunjuk kepada semua jenis perjanjian baik perjanjian bernama maupun perjanjian tidak bernama.

Perjanjian tidak bernama adalah perjanjian yang lahir kemudian karena perkembangan masyarakat. Meskipun perjanjian tersebut tidak ada nama dan pengaturannya dalam KUH Perdata, maka atas dasar asas kebebasan berkontrak, perjanjian tersebut bolehboleh saja dikembangkan di Indonesia. Pasal 1319 KUH Perdata menyatakan: "Semua perjanjian, baik yang mempunyai suatu nama khusus, maupun yang tidak terkenal dengan suatu nama tertentu, tunduk pada peraturanperaturan umum, yang termuat dalam bab ini dan bab yang lalu”. Pasal 1319 KUH Perdata ini membuka ruang diakuinya perjanjian tidak bernama dalam sistem hukum perjanjian dengan syarat perjanjian tidak bernama tersebut tetap tunduk pada peraturan-peraturan umum dalam hukum perjanjian.

Diakuinya keberadaan perjanjian tidak bernama ini ditegaskan kembali oleh Pasal 1338 ayat (1) KUH Perdata, bahwa sepanjang perjanjian itu dibuat secara sah, maka perjanjian tersebut mengikat sebagai undang-undang bagi yang membuatnya. Perjanjian yang dibuat secara "sah" merujuk kepada Pasal
1320 KUH Perdata mengenai syarat sahnya suatu perjanjian.

Salah satu bentuk perjanjian tidak bernama adalah perjanjian leasing. Istilah leasing berasal dari kata lease dalam bahasa Inggris. Perjanjian leasing bisa disandingkan dengan perjanjian sewa menyewa namun tidak persis sama makna antara leasing dengan sewa menyewa. Kata lease selalu merujuk pada adanya hubungan jangka waktu lease dengan unsur ekonomis benda yang menjadi objeknya, sedangkan hal itu tidak ada dalam perjanjian sewa menyewa (rent). ${ }^{1}$

Dengan tidak adanya pengaturan tentang leasing dalam KUHPerdata, maka leasing termasuk jenis perjanjian tidak bernama. Dilihat dari sejarahnya, lembaga leasing tidak tumbuh di negara-negara yang menganut sistem Eropah Kontinental tetapi tumbuh dan berkembang pertama kali di negara-negara yang menganut sistem Common Law. Leasing dalam arti modern berkembang pertama kali di Amerika Serikat, kemudian menyebar ke Eropah bahkan ke seluruh dunia termasuk Indonesia. Mengingat leasing, tumbuh dan berkembang di negara-negara common law, sehingga tidak mengherankan kalau terdapat kesulitan untuk mengkategorikannya kedalam jenis perjanjian yang ada dalam KUH Perdata. Kesulitan yang sama juga ditemui dalam perjanjian tidak bernama yang lain khususnya yang tumbuh dan berkembang di negara-negara common law.

Meskipun leasing masuk klasifikasi perjanjian tidak bernama, tetapi kita masih bisa mencari dasar dari perjanjian ini dalam KUH Perdata dengan membandingkan karakteristiknya dengan jenis-jenis perjanjian bernama

1 Miranda Nasihin. 2012. Segala Hal Tentang Hukum Lembaga Pembiayaan. Yogyakarta: Buku Pintar, hlm.26 
yang ada, sehingga dapat ditemukan perbedaan dan persamaan perjanjian leasing dengan perjanjian-perjanjian tersebut, sehingga dapat diidentifikasi karakteristik dari perjanjian leasing ini.

Ada beberapa jenis perjanjian yang dapat digunakan untuk mengindentifikasi karakteristik perjanjian leasing. Perjanjian tersebut, yaitu:

1. Perjanjian Jual Beli;

2. Jual Beli dengan Angsuran;

3. Sewa Beli;

4. Sewa Menyewa.

Berikut ini akan kita uraikan perbedaan antara perjanjian leasing dengan beberapa perjanjian di atas:

\section{Perjanjian Jual Beli}

Batasan perjanjian jual beli diatur dalam Pasal 1457 KUH Perdata. Menurut ketentuan ini, jual beli adalah suatu perjanjian dengan mana pihak yang satu mengikatkan dirinya untuk menyerahkan suatu kebendaan, dan pihak yang lain untuk membayar harga yang telah dijanjikan. Unsur pokok dalam perjanjian jual beli adalah barang dan harga.

Perjanjian dalam KUH Perdata sebagian besar bersifat obligator, artinya baru melahirkan hak dan kewajiban antara para pihak, sedangkan untuk peralihan hak milik memerlukan suatu perbuatan hukum lain yang disebut dengan levering atau penyerahan. Perbedaan pokok antara perjanjian jual beli dengan leasing adalah pada peralihan hak milik atas barang. Jual beli merupakan salah satu sarana untuk memindahkan hak milik. Pada leasing, peralihan hak milik baru terjadi apabila lessee menggunakan hak opsinya. Dan inipun hanya berlaku untuk jenis financial lease sedangkan untuk operating lease hal ini tidak terjadi karena begitu masa leasing berakhir lessee wajib mengembalikan barang leasing kepada lessor. Pada operating lease tujuan dari lessee hanya untuk mengambil manfaat dari barang modal bukan untuk memiliki barang modal. Oleh karena itu, dalam operating lease tidak ada hak opsi.

\section{Jual Beli dengan Angsuran}

Jual beli dengan angsuran merupakan bentuk derivatif dari perjanjian jual beli. Jual beli dengan angsuran adalah jual beli barang di mana penjual melaksanakan penjualan barang dengan cara menerima pelunasan pembayaran yang dilakukan oleh pembeli dengan beberapa kali angsuran atas harga barang yang telah disepakati bersama dan diikat dalam suatu perjanjian, serta hak milik atas barang tersebut beralih dari penjual kepada pembeli. ${ }^{2}$

Sama halnya dengan jual beli biasa, maka dalam jual beli dengan angsuran pun perbedaannya ada pada peralihan hak milik. Meskipun dalam jual beli dengan angsuran pembayarannya belum lunas, tetapi hak milik sudah beralih sejak barang diserahkan; sedangkan dalam perjanjian leasing, angsuran yang dibayar lessee kepada lessor bukanlah cicilan atas barang tetapi harga sewa dari barang modal yang digunakan oleh lessee.

\section{Perjanjian Sewa Beli}

Perjanjian sewa beli tidak diatur dalam KUH Perdata tetapi konstruksi hukumnya diterima dalam praktik dan dunia perdagangan. Sewa beli (hire purchase) adalah jual beli barang di mana penjual melaksanakan penjualan barang dengan cara memperhitungkan setiap pembayaran yang dilakukan pembeli dengan pelunasan atas harga barang yang telah disepakati bersama dan yang diikat dalam suatu perjanjian, serta hak milik atas

2 Abdulkadir Muhammad dan Rilda Murniati. 2000. Lembaga Keuangan dan Pembiayaan. Bandung: Citra Aditya Bakti, hlm. 33. 
barang tersebut baru beralih dari penjual kepada pembeli setelah jumlah harganya dibayar lunas oleh pembeli kepada penjual). ${ }^{3}$ Pada prinsipnya dalam perjanjian sewa beli selama cicilan belum lunas, kedudukan pembeli sewa hanya sebagai penyewa belaka. Setelah seluruh cicilan lunas maka pada saat itulah pembeli sewa akan menjadi pembeli dan menjadi pemilik dari barang yang disewa tadi. Dengan kata lain, peralihan hak milik terjadi setelah seluruh cicilan lunas

Perbedaan pokok antara sewa beli dengan leasing adalah pada saat berakhirnya masa sewa, pembeli sewa secara otomatis berubah statusnya dari penyewa menjadi pemilik barang; sedangkan pada leasing khususnya untuk jenis financial lease tergantung pada digunakan atau tidaknya hak opsi. Persamaan antara keduanya adalah pada masa sewa sedang berlangsung keduanya sama-sama berkedudukan sebagai penyewa.

\section{Perjanjian Sewa Menyewa}

Perjanjian sewa menyewa diatur dalam Pasal 1548 KUH Perdata, yang menyatakan: "Sewa menyewa adalah suatu perjanjian dengan mana pihak yang satu mengikatkan dirinya untuk memberikan kepada pihak yang lainnya kenikmatan dari sesuatu barang selama suatu waktu tertentu dan dengan pembayaran suatu harga yang oleh pihak yang tersebut terakhir itu disanggupi pembayarannya". Dari definisi sewa menyewa tersebut, ada beberapa hal yang dapat disimpulkan, yakni: pihak yang satu menyerahkan barangnya untuk dinikmati oleh pihak yang lain, sedangkan kewajiban yang terakhir ini adalah membayar harga sewa. Jadi, barang yang diserahkan tidak untuk dimiliki seperti halnya dalam jual

3 Ahmad Muliadi. 2013. Hukum Lembaga Pembiayaan. Jakarta: Akademia Permata, hlm. 32. beli, tetapi hanya untuk dipakai, dinikmati kegunaannya. Dengan demikian penyerahan hanya bersifat menyerahkan kekuasaan belaka atas barang yang disewa itu. ${ }^{4}$

Kewajiban pihak yang menyewakan adalah menyerahkan barang untuk dinikmati dan bukannya menyerahkan hak milik atas barang, maka ia tidak usah pemilik dari barang tersebut. Seorang yang mempunyai hak menikmati hasil dapat secara sah menyewakan barang yang dikuasainya tersebut. ${ }^{5}$ Penyerahan barang untuk dinikmati kegunaannya tersebut dibatasi untuk jangka waktu tertentu. Setelah jangka waktu sewa berakhir, penyewa wajib mengembalikan barang kepada pihak yang menyewakan.

Apabila dibandingkan antara perjanjian leasing dengan perjanjian sewa menyewa, ada beberapa perbedaan, yaitu:

1. Objek leasing meliputi segala macam barang modal mulai dari pesawat terbang hingga mesin-mesin dan komputer untuk keperluan perkantoran. Sedangkan untuk objek sewa menyewa adalah barang pada umumnya baik itu barang untuk keperluan produksi maupun untuk keperluan konsumsi;

2. Pembayaran secara berkala dalam jangka waktu tertentu. Dalam sewa menyewa biasanya cara pembayaran dilakukan dilakukan sekali untuk suatu periode tertentu, sedangkan pada leasing disini pembayarannya dilakukan secara berkala dan bisa dilakukan setiap bulan, setiap kuartal atau setiap setengah tahun sekali;

3. Nilai sisa atau residual value. Pada perjanjian leasing ditentukan suatu nilai sisa, sedangkan perjanjian sewa menye-

$4 \quad$ Ibid., hlm. 40.

5 Subekti. 1989. Aneka Perjanjian. Bandung: Citra Adiya Bhakti, hlm. 40. 
wa tidak mengenal hal itu;

4. Hak opsi bagi lesssee. Pada akhir masa leasing, lessee mempunyai hak untuk menentukan apakah ia ingin membeli barang tersebut dengan harga sebesar nilai sisa ataukah mengembalikan kepada lessor, sedangkan dalam perjanjian sewa menyewa jika masa sewa telah berakhir, penyewa wajib mengembalikan barang tersebut kepada pihak yang menyewakan;

5. Pihak-pihak yang terlibat dalam perjanjian leasing adalah lessor dan lessee. Pada perjanjian sewa menyewa siapa saja bisa menjadi lessor. Tetapi dalam perjanjian leasing, hanya perusahaan-perusahaan yang mendapat izin dari departemen keuangan (baca Otoritas Jasa Keuangan) saja yang boleh menjadi lessor. ${ }^{6}$

Mengingat ada berbagai unsur dalam leasing tentulah sulit meletakannya ke dalam salah satu jenis perjanjian yang sebagaimana yang ada dalam buku III KUH Perdata, sehingga pasal-pasal terkait jual beli dan sewa menyewa tidak dapat diperlakukan sepenuhnya kedalam perjanjian leasing. Perjanjian leasing memiliki karakteristik khusus, karena mengandung berbagai macam unsur perjanjian, yakni: ada unsur jual beli, unsur sewa beli dan unsur sewa menyewa. Dengan demikian dapatlah dikatakan bahwa leasing termasuk jenis perjanjian campuran. Adanya berbagai macam unsur dalam perjanjian leasing, yang banyak menimbulkan kerancuan dalam praktik di masyarakat. Kerancuan juga terjadi pada pengikatan jaminan terhadap perjanjian leasing yang menyamakan semua jenis leasing padahal masing-masing leasing mempunyai cirinya yang tentunya memiliki konsekuensi masing-masing sesuai dengan jenisnya.

6 Soekadi, Eddy P. 1986. Mekanisme Leasing. Jakarta: Ghalia Indonesia. hlm. 15-16.
Kesulitan dalam mencari bentuk hukum yang pas tentang leasing ini, sehingga ada yang mengatakannya sebagai pranata hukum yang "banci". Di satu pihak mirip sewa menyewa, di lain pihak mengandung unsur jual beli, bahkan juga ada unsur pinjam meminjamnya. Karena itu, beberapa segi realisasi leasing dalam praktik masih terkesan banci dan ragu-ragu. ${ }^{7}$

\section{Objek Leasing Yang Diikat Dengan Jami- nan Fidusia}

Leasing menurut ketentuan The Equipment Leasing Association di London Inggeris sebagaimana yang dikutip oleh Amin Widjaja Tunggal dan ArifDjohan Tunggal adalah "perjanjian atau kontrak antara lessor dan lessee untuk menyewa suatu jenis barang modal tertentu yang dipilih atau ditentukan oleh lessee. Hak atas kepemilikan barang modal tersebut ada pada lessor, adapun lessee hanya menggunakan barang modal tersebut berdasarkan pembayaran uang sewa yang telah ditentukan dalam suatu jangka waktu tertentu). ${ }^{8}$

Sementara itu menurut Pasal 1 angka 5 Peraturan Presiden Nomor 9 Tahun 2009 tentang Lembaga Pembiayaan (untuk selanjutnya disebut Perpres No. 9/2009), leasing atau sewa guna usaha adalah kegiatan pembiayaan dalam bentuk penyediaan barang modal baik secara sewa guna usaha dengan hak opsi (finance lease) maupun sewa guna usaha tanpa hak opsi (operating lease) untuk digunakan oleh penyewa guna usaha (lessee) selama jangka waktu tertentu berdasarkan pembayaran secara angsuran.

7 Munir Fuady. 1995. Hukum Tentang Pembiayaan dalam Teori dan Praktik. Bandung: Citra Aditya Bakti, hlm. 5.

8 Sunaryo. 2013. Hukum Lembaga Pembiayaan. Jakarta: Sinar Grafika, hlm. 47. 
Dari ketentuan tersebut di atas, maka terdapat 2 (dua) macam leasing (sewa guna usaha) yaitu:

1. sewa guna usaha dengan hak opsi ( $f$ nance lease), dan

2. sewa guna usaha tanpa hak opsi (operating lease).

Dalam perjanjian sewa guna usaha dengan hak opsi (finansial lease) pada akhir masa kontrak, lesse mempunyai hak untuk memilih apakah akan:

a. membeli barang modal sesuai dengan nilai sisa (residual value) yang telah disepakati sebelumnya, atau

b. mengembalikannya kepada lessor, atau

c. memperpanjang masa kontrak sesuai dengan syarat-syarat yang telah disetujui bersama). ${ }^{9}$

Jadi, dalam sewa guna usaha dnegan hak opsi ini, lessee diberikan opsi atau diberi pilihan apakah mau membeli barang yang menjadi objek perjanjian leasing, mengembalikan ataukah memperpanjang masa sewa (masa leasing). Apabila lessee memilih mau membeli barang yang menjadi objek perjanjian tersebut, maka lessee harus membayar nilai sisa. Sejak dibayarnya nilai sisa, maka sejak itu terjadi peralihan hak milik atas barang yang menjadi objek leasing dari lessor kepada lessee. Hal ini sesuai dengan ketentuan Pasal 3 ayat (3) Peraturan Menteri Keuangan Nomor 84/PMK.012/2006 tentang Perusahaan Pembiayaan (untuk selanjutnya disebut PMK No. 84/2006). Menurut ketentuan tersebut, menyatakan bahwa sepanjang perjanjian sewa guna usaha masih berlaku, hak milik atas barang modal objek transaksi sewa guna usaha berada pada perusahaan pembiayaan.

Namun di dalam praktiknya di lapangan,

9 Abdulkadir Muhammad dan Rilda Murniati. $O p$ cit, hlm. 205. seringkali objek leasing diikat dengan jaminan fidusia, apakah hal ini merupakan sesuatu yang diperlukan ataukah merupakan suatu perbuatan yang sebenarnya tidak diperlukan. Untuk itu sekarang kita lihat konstruksi dari jaminan fidusia.

Jaminan fidusia lahir sebagai jawaban atas kekurangan dari lembaga jaminan yang diatur dalam KUHPerdata, yaitu lembaga jaimnan gadai dan lembaga jaminan hipotik. Selama ini kita mengenal untuk benda bergerak digunakan lembaga gadai, dimana benda yang dijaminkan diserahkan oleh pemberi gadai kepada pemegang gadai, sedangkan untuk benda tidak bergerak diikat dengan jaminan hipotik.

Akan tetapi ada kalanya kebutuhan dalam praktik untuk menjaminkan barang bergerak, tetapi tanpa persyaratan barang secara fisik (karena barang jaminan akan digunakan oleh debitur untuk keperluan usahanya), maka untuk maksud tersebut tidak dapat digunakan lembaga gadai (yang mensyaratkan penyerahan barang jaminannya) dan juga tidak dapat menggunakan lembaga hipotik yang hanya diperuntukkan terhadap barang tidak bergerak saja). Oleh karena itu dicarilah jalan keluar untuk dapat menjaminkan barang bergerak tanpa penyerahan fisik barang tersebut. Akhirnya muncullah suatu rekayasa untuk kepentingan praktik, dengan jalan pemberian jaminan fidusia. ${ }^{10}$

Rekayasa hukum dimaksud dilakukan lewat bentuk globalnya yang disebut dengan "constitutum posessorium", yaitu penyerahan kepemilikan benda tanpa menyerahkan fisik benda sama sekali. Bentuk rincian dari "constitutum posessorium" tersebut dalam jaminan fidusia ini pada prinsipnya dilakukan

10 Munir Fuady. 2003. Jaminan Fidusia. Bandung: Citra Aditya Bakti, hlm. 5. 
melalui proses 3 (tiga) fase, sebagai berikut: ${ }^{11}$

(a) Fase Perjanjian obligator (obligator overeenkomst)

Dari segi hukum dan dari segi dokumentasi hukum, maka proses jaminan fidusia diawali oleh adanya suatu perjanjian obligator (obligator overeenkomst). Perjanjian obligator tersebut berupa perjanjian pinjam uang dengan jaminan fidusia diantara pihak pemberi fidusia (debitur) dengan pihak penerima fidusia (kreditur).

(b) Fase Perjanjian Kebendaan (zakelijke overeenkomst)

Dalam fase kedua ini diikuti dengan suatu perjanjian kebendaan (zakelijke overeenkomst).Perjanjian kebendaan tersebut berupa penyerahan hak milik dari debitur kepada kreditur, dalam hal dilakukan secara "constitutum posessorium", yaitu penyerahanhak milik tanpa penyerahan fisik bendanya.

(c) Fase Perjanjian Pinjam Pakai

Dalam fase ketiga ini dilakukan perjanjian pinjam pakai, dalam hal ini benda objek fidusia yang hal miliknya sudah berpindah dari pihak debitur kepada pihak kreditur dipinjampakaikan oleh pihak kreditur kepada pihak debitur, sehingga secara praktis benda tersebut setelah diikat dengan jaminan fidusia tetap saja secara fisik dikuasai oleh pihak debitur.

Sebenarnya konstruksi fidusia dengan tiga fase tersebut adalah konstruksi rekayasa sekedar untuk mencari jalan agar dapat dijadikan jaminan atas benda bergerak tanpa perlu menyerahkan benda secara fisik kepada kreditur. Jadi yang dimaksudkan dari semula dalam konstruksi ini adalah "jaminan terhadap hutang", bukan dimaksudkan sebagai peralihan

11 Ibid, hlm. 5-6. hak milik. ${ }^{12}$ Akan tetapi UU No. 42/1999 dalam Pasal 1 angka 1 menyatakan: "Fidusia adalah pengalihan hak kepemilikan suatu benda atas dasar kepercayaan dengan ketentuan bahwa benda yang hak kepemilikannya dialihkan tersebut tetap dalam penguasaan pemilik benda". Makna dari pengalihan kepemilikan adalah pemindahan hak kepemilikan dari pemberi fidusia kepada penerima fidusia atas dasar kepercayaan, dengan syarat bahwa benda yang menjadi objeknya tetap berada di tangan pemberi fidusia. Sehubung dengan itu, A. Hamzah dan Senjun Manulang mengartikan fidusia sebagai berikut:

Suatu cara pengoperan hak milik dari pemiliknya (debitur) berdasarkan adanya perjanjian pokok (perjanjian utang piutang) kepada kreditur, akan tetapi yang diserahkan hanya haknya saja secara yuridise-levering dan hanya dimiliki oleh kreditur secara kepercayaan saja (sebagai jaminan utang debitur), sedangkan barangnya tetap dikuasai oleh debitur, tetapi bukan lagi sebagai eigenaar maupun bezitter melainkan hanya sebagai detentor atau houder dan atas nama kreditur. ${ }^{13}$

Definisi ini didasarkan pada konstruksi hukum adat, karena istilah yang digunakan adalah pengoperan. Pengoperan diartikan sebagai suatu proses atau cara mengalihkan hak milik kepada orang lain. Disamping istilah fidusia dikenal juga istilah jaminan fidusia sebagaimana diatur dalam Pasal 1 angka 2 UU No. 42/1999 seperti uraian di atas.

Jadi, pada prinsipnya UU No. 42/1999 tetap memberlakukan fidusia dengan konsep penyerahan hak milik, tidak semata-mata

12 Ibid.

13 Salim HS . 2012. Perkembangan Hukum Jaminan di Indonesia. Jakarta:Raja Grafindo Persada, hlm. 56. 
jaminan saja. Hal ini terlihat antara lain dari pengakuan pembentuk undang-undang lewat Penjelasan resmi Pasal 17, yang menyatakan bahwa "Fidusia ulang oleh pemberi fidusia, baik debitur maupun penjamin pihak ketiga, tidak dimungkinkan atas benda yang menjadi objek jaminan fidusia karena hak kepemilikan atas benda tersebut telah beralih kepada penerima fidusia".

Terkait dengan objek leasing yang diikat dengan jaminan fidusia, padahal dalam perjanjian sewa guna usaha, hak milik atas barang modal objek transaksi sewa guna usaha masih berada pada perusahaan pembiayaan sepanjang perjanjian belum berakhir. Objek leasing masih menjadi hak milik lessor (kreditur), bukan milik lessee (debitur), sementara "fidusia merupakan pengalihan kepemilikan....." Makna dari pengalihan kepemilikan adalah pemindahan hak kepemilikan dari pemberi fidusia kepada penerima fidusia atas dasar kepercayaan, dengan syarat bahwa benda yang menjadi objeknya tetap berada di tangan pemberi fidusia.

Kalau objek leasing diikat dengan jaminan fidusia, berarti akan dilakukan pengalihan hak kepemilikan dari pemberi fidusia (debitur/lessee) kepada penerima fidusia (kreditur/ lessor), padahal selama perjanjian leasing berlangsung hak milik atas objek leasing masih berada di tangan lessor/kreditur. Oleh karena itu sebenarnya pengikatan jaminan fidusia terhadap objek leasing merupakan suatu hal yang berlebihan dan tidak diperlukan, karena selama perjanjian leasing berlangsung objek perjanjian leasing masih milik lessor.

Namun dalam praktiknya di lapangan seringkali terjadi penyelundupan hukum di mana objek leasing diikat dengan jaminan fidusia, hal ini dilakukan oleh perusahaan pembiayaan (lessor), disebabkan karena status kepemilikan objek leasing sejak awal perjanjian sudah atas nama lessee, hal ini ditempuh lessor karena sudah ada kesepakatan kalau lessee pada akhir perjanjian nantinya akan menggunakan hak opsinya, yaitu membayar nilai sisa yang telah disepakati sebelumnya.

Berikut ini beberapa contoh klausula dalam beberapa perjanjian leasing yang mengindikasikan hal tersebut: ${ }^{14}$

(1) Perjanjian leasing di PT. BFI FINANCE

Pada Pasal 7 ayat (1) dinyatakan :

"Lessee dengan ini mengakui bahwa lessor adalah pembeli dan oleh karena itu sejak tanggal pencairan fasilitas, lessor adalah satu-satunya pemilik barang modal, terlepas dari ada atau tidaknya surat pernyataan penerimaan barang modal dan demikian selanjutnya, maka selama perjanjian ini (masih) berlangsung, berdasarkan ketentuan Pasal 3 ayat (3) Peraturan Menteri Keuangan Republik Indonesia Nomor 84/PMK.012/2006, lessor adalah tetap sebagai pemilik barang modal, sedangkan lessee hanyalah sebagai sebagai penyewa guna usaha saja, meskipun atau seandainya pun dalam dokumen-dokumen kepemilikan nama lessee atau nama lain siapa saja”.

(2) Perjanjian leasing di PT. MURNI UPAYA RAYA NILAI INTI FINANCE

Pasal 5 ayat (1) menyatakan :

"Dengan ditandatanganinya perjanjian ini, dan selanjutnya selama jangka waktu perjanjian, dengan sendirinya hak milik atas barang yang dileasekan adalah ke-

14 Nano Sutejo. 2011. Kedudukan Hukum Lessor dalam Perjanjian Leasing yang Objek Leasingnya Diatasnamakan Lessee. Tesis. Banjarmasin: Program Magister Ilmu Hukum Universitas Lambung Mangkurat, hlm. 119. 
punyaan atau telah dialihkan pada lessor secara tanpa syarat, dan tidak akan berubah atau berakhir karena alasan atau sebab apapun juga sekalipun dalam hal bukti kepemilikan barang itu tertulis atas nama lessee atau atas nama pihak ketiga”.

(3) Perjanjian leasing di PT. HOT PIR GEMILANG LEASE

Pada Pasal 5 ayat (1) dinyatakan :

"Pada saat ditandatanganinya perjanjian ini, dan selama jangka waktu perjanjian, maka hak milik atas barang yang dileasekan adalah dialihkan kepada lessor dengan atau tanpa syarat, dan tidak akan berubah atau berakhir karena alasan atau sebab apapun juga sekalipun dalam hal bukti kepemilikan barang yang dileasekan itu tertulis atau terdaftar $\underline{\text { atas }}$ nama lessee atau atas nama pihak ketiga."

Upaya lessor (perusahaan pembiayaan) mencantumkan nama lessee di bukti kepemilikan barang yang menjadi objek leasing dengan tujuan untuk efesiensi dan efektifitas serta kemungkinan karena sudah ada kesepakatan antara lessor dan lessee kalau diakhir perjanjian leasing, lessee akan menggunakan hak opsinya dengan membeli objek leasing dan membayar sejumlah nilai residu.

Posisi seperti ini sebenarnya sangat membahayakan dan merugikan lessor sendiri, karena kalau terjadi lessee wanprestasi, maka secara hukum lessor tidak mempunyai kekuatan hukum untuk mengeksekusi barang yang merupakan objek leasing yang berada di dalam penguasaan lessee. Untuk mengatasi hal tersebut, maka oleh lessor di dalam per- janjian leasing dibuat klausula yang menyatakan bahwa barang objek leasing tersebut sekaligus sebagai jaminan dalam perjanjian leasing tersebut. Dalam kasus seperti ini lessor merasa perlu mengikat objek perjanjian leasing dengan jaminan fidusia dikarenakan objek leasing sudah diatasnamakan lessee.

Lessor yang mengatasnamakan objek leasing atas nama lessee dengan alasan efesiensi dan kemudian mengikat objek leasing tersebut dengan jaminan fidusia jelas mengandung risiko yang besar dan berpotensi menimbulkan kerugian bagi lessor, karena kalau terjadi wanprestasi, walaupun lessor dapat mengeksekusi objek leasing yang diikat dengan jaminan fidusia, namun yang harus diingat posisi lessor bukan sebagai pemilik yang menguasai benda miliknya (bezitter-eigenaar), tetapi hanya sebagai pemegang hak jaminan fidusia, sehingga kalau objek leasing tersebut dieksekusi oleh pengadilan, maka lessor hanya menjual barang miliknya sendiri dan uang yang didapatkan lessor hanyalah pelunasan sejumlah angsuran yang belum dilunasi oleh lessee, sedangkan sisa uang penjualan kembali kepada lessee.

Kalau sejak dari awal perjanjian leasing objek leasing sudah diatasnamakan lessee, maka perjanjian leasing ini sudah kehilangan essensinya sebagai perjanjian leasing, karena kalau dalam perjanjian leasing, lessee baru menjadi pemilik benda yang menjadi objek jaminan kalau lessee melakukan dua hal, yaitu: (1) menggunakan hak opsinya dengan cara membeli objek leasing; dan (2) lessee harus membayar sejumlah nilai sisa. Hal ini sesuai makna yang terkandung dalam 
Pasal 3 ayat (3) PMK No.84/2006.

Jadi dalam perjanjian leasing, levering (penyerahan yang mengakibatkan beralihnya hak milik) tidak terjadi sejak transaksi leasing dilakukan, tetapi setelah hak opsi tersebut dilaksanakan oleh lessee, yaitu pada akhir masa leasing. ${ }^{15}$

\section{PENUTUP}

Perjanjian leasing memiliki karakteristik tertentu, sebab di dalamnya mengandung paling tidak ada tiga jenis perjanjian yakni perjanjian jual beli, perjanjian sewa beli dan perjanjian sewa menyewa. Dikatakan pula perjanjian leasing merupakan sebuah perjanjian campuran yang mengandung paling tidak ada tiga jenis perjanjian didalamnya.Terdapat kesulitan dalam memposisikan pranata hukum leasing kedalam sistem hukum perjanjian Indonesia. Ada ahli yang menyatakan leasing sebagai pranata hukum yang "banci" karena banyaknya unsur-unsur dari perjanjian lain yang tercakup didalamnya. Keadaan ini berakibat terjadinya kerancuan dalam praktik perjanjian leasing yang dilakukan oleh perusahaan-perusahaan pembiayaan.

Pada perjanjian leasing, selama perjanjian leasing berlangsung kepemilikan objek leasing berada ditangan lessor (perusahaan pembiayaan/kreditur), bukan berada di tangan lessee (debitur). Apabila perjanjian leasing diikat dengan jaminan fidusia, maka hal ini merupakan perbuatan yang berlebihan, karena yang dinamakan fidusia adalah penyerahan hak kepemilikan suatu benda dari debitur kepada kreditur, sementara dalam perjanjian leasing objeknya masih milik kreditur.

Dalam praktik di lapangan dengan alasan efesiensi, seringkali objek leasing sejak awal perjanjian sudah diatasnamakan lessee,

15 Munir Fuady. Op.cit., hlm. 30. dengan demikian kepemilikan objek leasing sudah atas nama lessee, sehingga untuk menghindari kekhawatiran kalau lessee wanprestasi, lessor melengkapi perjanjian leasing tersebut dengan klausula jaminan fidusia. Hal ini tentunya sangat beresiko bagi lessor, karena lessor bukan lagi sebagai eigenaar terhadap objek perjanjian leasing, tetapi hanya sebagai pemegang hak jaminan fidusia, sehingga kalau objek leasing tersebut dieksekusi oleh pengadilan, maka lessor hanya menjual barang miliknya sendiri dan uang yang didapatkan lessor hanyalah pelunasan sejumlah angsuran yang belum dilunasi oleh lessee, sedangkan sisa uang penjualan dikembalikan kepada lessee.

\section{BIBLIOGRAFI}

Soekadi, P Eddy. 1986. Mekanisme Leasing. Jakarta: Ghalia Indonesia.

Subekti. 1989. Aneka Perjanjian. Bandung: Citra Aditya Bakti.

Andasasmita, Komar. 1989. Serba Serbi tentang Leasing (Teori dan Praktek). Bandung: INI Komisariat Jawa Barat.

Fuady, Munir. 1995. Hukum tentangPembiayaan Dalam Teori Dan Praktek. Bandung: Citra Aditya Bakti.

Muhammad, Abdul Kadir dan Rilda Murniati. 2000. Lembaga Keuangan Dan Pembiayaan. Bandung: Citra Aditya Bakti.

Fuady, Munir. 2003. Jaminan Fidusia. Bandung: Citra Aditya Bakti.

Umam, Khotibul. 2010. Hukum Lembaga Pembiayaan Hak dan Kewajiban Nasabah Pengguna Jasa Lembaga Pembiayaan. Yogyakarta: Pustaka Yustisia.

Nasihin, Miranda. 2010. Segala Hal Tentang Hukum Lembaga Pembiayaan. Yogyakarta: Buku Pintar.

Sutejo, Nano. 2011. Kedudukan HukumLes- 
sor Dalam Perjanjian Leasing Yang Objek Leasingnya Diatasnamakan Lessee. Tesis. Banjarmasin: Program Magister Ilmu Hukum Universitas Lambung Mangkurat.

Salim HS. 2012. Perkembangan Hukum Jaminan di Indonesia. Jakarta: Raja Grafindo Persada.

Muliadi, Ahmad. 2013. Hukum Lembaga Pembiayaan. Jakarta: Akademia Permata.

Sunaryo. (2013). Hukum Lembaga Pembiayaan. Jakarta: Sinar Grafika.

\section{Peraturan Perundang-undangan}

Kitab Undang-undang Hukum Perdata (Staatsblad) Tahun 1847 Nomor 23.

Undang-Undang Nomor 4 Tahun 1996 tentang Hak Tanggungan Atas Tanah Beserta Benda-benda yang Berkaitan dengan Tanah Lembaran Negara Republik Indonesia Tahun 1996 Nomor 42, Tambahan Lembaran Negara Republik Indonesia Nomor 3632.

Undang-Undang Nomor 42 Tahun 1999 tentang Jaminan Fidusia Lembara Negara Republik Indonesia Tahun 1999 Nomor 168, Tambahan Lembaran Negara Republik Indonesia Nomor 3889.

Peraturan Menteri Keuangan Nomor 84/ PMK.012/2006 tentang Perusahaan Pembiayaan.

Peraturan Presiden Nomor 9 Tahun 2009 tentang Lembaga Pembiayaan. 